UDK: 336.717.061(100)

DOI: $10.1515 /$ jcbtp-2016-0017

Journal of Central Banking Theory and Practice, 2016, 3, pp. 5-29

Received: 2 October 2015; accepted: 10 January 2016

Indranarain Ramlall *

\title{
Does Central Bank Quality Determine Sovereign Ratings and Credit Default Swap Spreads: Evidence from the World?
}

\begin{abstract}
This study innovates from prior research which focuses on the determinants of sovereign ratings and credit default swap spreads for a large sample of countries by incorporating the quality of central banks, let alone refined proxies. Findings show that the explanatory power of both sovereign ratings and CDS spreads model improve by a hefty 11 percent in case of sovereign ratings and 6 to 9 percent in the case of CDS spreads when central bank quality is incorporated. Such a finding bolters the notion that institutional quality does play a preponderant role when it comes to assessing country risk, making it a systematic component of institutional quality. The effect of labour participation implies that countries buffeted by stronger effects of an ageing population have greater propensity of increases in CDS spreads. Evidence is also found as to the driving dynamics of CDS spreads and sovereign ratings to be distinct. Our results hold robust post tackling for endogeneity problem.
\end{abstract}

Keywords: Central Banking, Credit Default Swap Spreads, Sovereign ratings, Country risk analysis

JEL CODE: E02, E58, F30, G00

\section{Introduction}

Credit ratings capture forward-looking opinions of rating agencies with respect to creditworthiness of borrowers. Three internationally coveted Credit Rating Agencies (CRAs) have received substantial attention, namely Standard and Poor's 
Ratings Services, Moody's Investors Service and Fitch Rating agency. In the last decade, sovereign ratings analysis has gained considerable momentum on the back of a plethora of reasons. First, there is emphasized need for sound country risk analysis by global investors in view of enhancing the process of top-down investment strategies. This manifests in form of information asymmetry mitigation mechanism inherently embedded in credit ratings which "greases" the interaction between bond issuers and global investors. Second, heightened stress and disciple are relentlessly being exerted on government in order to ensure sound financial market activities and this has been rekindled by the US subprime crisis. Third and perhaps most importantly, certain economic underpinnings are attached to credit ratings. Strong ratings ease access to funding in international financial markets, lure foreign investments, improve credibility of foreign currency-denominated bonds and scale down interest rates for borrowing countries. Fourth, sovereign risk has been the subject of intense analysis as it impacts on corporate risk. Many studies have been undertaken in that dimension such as those of Klein and Stellner (2014) and Cavallo and Valenzuela (2010). The last but not the least, credit ratings can be particularly detrimental to the economic health of economies. Pro-cyclical ratings gnaw at economies buffeted by distinct conditions as stressed by Ferri et al. (1999). Similarly, CRAs accentuated the East Asian crisis via pro-cyclical ratings.

Credit ratings for both private and public entities have come under intense scrutiny since the onset of the 2008 financial crisis. CRAs have been heavily criticized for failing to identify the amount of risk embedded in mortgage-backed securities in the United States during the lending boom of the 2000s which was propelled by excessively accommodative monetary policy stance. Following the recent downgrades of a number of eurozone sovereigns, CRAs were accused of exacerbating the eurozone debt crisis and contributing to the rising borrowing costs. The current study adds to the empirical literature on sovereign ratings and Credit Default Swap (CDS) spreads by giving due consideration to a new and key variable, namely, the quality of central banks, which is captured by a large set of qualitative and quantitative metrics. Such a new variable is captured by a unique set of central bank ratings developed by Ramlall (2015). The aim is to sieve out as to whether central bank quality unleashes impacts on a country's level of risk assessment. Findings glaringly show that central bank quality unleashes 11 percent increase in the explanatory power of sovereign ratings and 6 to 9 percent increase in the case of credit default swap spreads models. Furthermore, the paper adds on refined proxies for reserves and unemployment by using import cover and labour participation.

This paper is organized as follows. Section 2 focuses on the literature review while section 3 deals with the data and econometric model. Section 4 probes into the 
empirical results. Section 5 focuses on the endogeneity problem. Finally, section 6 concludes.

\section{Literature review}

The empirical literature on sovereign risk analysis is imbued with various streams of assessments. First, studies are based either on determinants of ratings or causality of ratings. Second, the econometric method applied differs such as the use of cross-sectional ordinary least squares (Cantor and Packer (1996) and Afonso (2003)), logit and probit models (Afonso et al. (2007)) and ordered response model (Bissoondoyal-Bheenick (2005)). Third, there are two strands of studies, those based on one period focus (like Afonso (2003) and Butler and Fauver (2006)) compared to those studies which are based on the use of several time periods such as those of Alesina et al. (1992), Hill et al. (2010) and Rowland and Torres (2004). Despite different ways of analysis, nevertheless, all studies employ a vector of nearly similar variables such as GDP per capita, inflation, debt, reserves and unemployment.

Kaminsky and Schmukler (2002) showed that changes in sovereign debt ratings and outlooks affected financial markets in emerging economies, with the average yield spreads scaling up by 2 percentage points in response to a one-notch downgrade. Sy (2002) found that a one-notch upgrade reduced sovereign spreads on average by 14 percent (or 70 basis points for an initial spread of 500 basis points). Furthermore, Hartelius et al. (2008) found that improvements in emerging market credit ratings explained the fall in sovereign spreads since mid-2002. Contrary to these findings, Gonzalez-Rozada et al. (2008) concluded that ratings were largely endogenous, reflecting changes in spreads rather than anticipating them, underscoring the importance of exogenous factors such as the international business cycle. Bozic and Magazzino (2013) explored a set of macroeconomic drivers in the case of sovereign ratings assessment for 139 countries in the period 1975-2010. Their findings demonstrated considerable impacts of the following variables, namely, GNI per capita, unemployment, inflation, fiscal balance, government debt and default history.

Oliveira, Curto and Nunes (2012) analyzed the determinants of government credit spreads in the euro area. They captured credit spreads as the difference between zero-coupon rates of government bonds from each country and the German Treasury spot rates. Prior to the crisis, they found that stock returns and interest rate sensitive variables (captured as level, slope and curvature of the reference yield curve) constituted the most vital determinants of credit spreads. Most 
importantly, evidence is found of low explanatory power in the case of country-specific macroeconomic fundamentals and European risk conditions. They attributed these findings to "convergence-trading hypothesis" characterized by convergence to the German economy in the pre-crisis episode. Post the crisis, they found a different state of affairs in that market behaviours were mainly affected by global volatility and country-specific macroeconomic fundamentals.

Afonso (2003) studied the key factors which determine sovereign debt ratings using cross-sectional data from 81 developed and developing countries, based on ratings assigned by Moody's and S\&P's in June 2001. Afonso (2003) concluded that six variables were the most relevant factors in explaining the credit ratings: (1) GDP per capita, (2) external debt-to-exports ratio, (3) level of economic development, (4) default history,(5) real growth rate, and (6) inflation rate. Afonso (2003) further deduced that GDP per capita emerged as virtually the sole relevant economic variable for developed countries, while external debt was important for developing countries.

Afonso et al. (2007) empirically examined the economic determinants of sovereign credit ratings for the period 1995-2005, employing panel estimation and ordered probit approaches with random effects. They found that GDP per capita, real GDP growth, government debt, government effectiveness, external debt and external reserves, sovereign default indicator, as well as being a member of the European Union, were the most important determinants of sovereign debt ratings. Their findings also showed that the external debt and external reserves constituted the most relevant variables for low-rated countries, while inflation played a more profound role for high-rated countries. Cantor and Packer (1996) estimated that about $80 \%$ of variations in credit ratings were explained by variations in per capita income, external debt burden, inflationary experience, default history, and the level of economic development. They concluded that there existed significant information content of macroeconomic indicators in the pricing of sovereign risk.

The sovereign ratings literature is replete of certain stylized factors. Given a downgrade by a specific rating agency, further downgrades by other CRAs occur with a high magnitude in the short-run, as underscored by Guttler and Wahrenburg (2007). In a parallel manner, Alsakka and Gwilyn (2010) pointed out the strong presence of interdependence conspicuously noted in ratings so that an upgrade probability is much higher and a downgrade probability is much lower for a sovereign entity which has been subject to a recent upgrade by another CRA. The reverse manifests in the case of a downgrade. Hill et al. (2010) argued that rating transition probabilities were likely to scale up as the rating level declined across all agencies.

The next section deals with the data parts and the estimation techniques. 


\section{Data and Econometric model}

Data have been gleaned from the World Bank Indicators, websites of Aswath Damodaran (2014) and Standard and Poor's and, various annual reports of central banks. The central bank quality data has been sourced from Ramlall (2015) who developed the ratings for central banks worldwide for the year 2013. Ramlall (2015) used central bank data for the period 2000 to 2013. Consequently, a crosssectional analysis is undertaken with macroeconomic data being averaged over the same period to level the playing field. The list of countries used in the study is found in the appendix section in table 1 . Since credit default swap spreads data are not available for all countries, a reduced but comfortable sample size is used. The econometric models are specified below.

Sovereign Ratings ${ }_{i}=\beta_{0}+\beta_{1}$ Central Bank Quality ${ }_{i}+\beta_{2} Z_{\text {-Score }}+\beta_{3}$ Legal $_{i}+$ $\beta_{4}$ Exchange rates $_{i}+\beta_{5}$ Credit $_{i}+\beta_{6}$ GDP per capita ${ }_{i}+\beta_{7}$ Public debt $_{i}+\beta_{8}$ Trade $_{i}+$ $\beta_{9}$ Labour participation $_{i}+\beta_{10}$ Import $_{\text {Cover }}+\beta_{11}$ Inflation $_{i}$

CDS Spreads $s_{i}=\beta_{0}+\beta_{1}$ Central Bank Quality $_{i}+\beta_{2}$ Z-Score $_{i}+\beta_{3}$ Legal $_{i}+$ $\beta_{4}$ Exchange rates $_{i}+\beta_{5}$ Credit $_{i}+\beta_{6}$ GDP per capita ${ }_{i}+\beta_{7}$ Public debt $_{i}+\beta_{8}$ Trade $_{i}+$ $\beta_{9}$ Labour participation $_{i}+\beta_{10}$ Import $_{\text {Cover }}+\beta_{11}$ Inflation $_{i}$

Model (1) focuses on sovereign ratings while model (2) is based on credit default swap spreads analysis. In line with prior studies, a vector of core independent variables are used, namely, GDP per capita, inflation, public debt and trade openness. However, to gain a full-fledged analysis, other explanatory variables are incorporated but which have not been widely used in prior studies such as strength of the legal system, the exchange rates, domestic credit and labour participation. In addition, a central bank z-score variable is included to gauge on the crude effect of central bank financial strength.

The independent variables used are mainly derived from previous studies which factor in core variables such as GDP per capita, inflation, trade openness, amongst others. In lieu of unemployment, labour participation is employed as it best captures the impact of labour involvement in the activities carried out in an economy. Another vital reason prevails for clinging to labour participation relates to the fact that only few studies (such as Bozic and Magazzino (2013)) used unemployment. In the same vein, import cover is used in lieu of reserves. Indeed, many studies such as those of Bissoondoyal-Bheenick (2005), Rowland and Torres (2004), Bozic and Magazzino (2013) employed reserves. However, the current study uses import cover because it constitutes a more realistic assessment of a 
country's resource endowment relative to its pressing needs while reserves merely reflect endowment assessment in isolation.

Table 2 below provides the definition of each of the variables used in the above models.

Table 2: Definition of variables

\begin{tabular}{|c|c|}
\hline Variable & Definition \\
\hline Sovereign ratings & $\begin{array}{l}\text { Value based on rating notch attributed by Standard and Poor's; } \\
\text { source: Standard and Poor's website (2014) }\end{array}$ \\
\hline CDS Spreads & $\begin{array}{l}\text { 10-year Credit Default Swap Spreads; source: website of Aswath } \\
\text { Damodaran (2014) }\end{array}$ \\
\hline Central Bank Quality & Based on rankings as developed by Ramlall (2015) \\
\hline Z-score & Computed using 10 -year' data from annual reports of central banks \\
\hline Legal & Strength of the legal system averaged over 10 years ; source: World Bank \\
\hline Exchange rates & $\begin{array}{l}\text { Exchange rates (base currency US dollar) averaged over } 10 \text { years; } \\
\text { source: World Bank }\end{array}$ \\
\hline Credit & $\begin{array}{l}\text { Domestic credit of banking sector over GDP averaged over } 10 \text { years; } \\
\text { source: World Bank }\end{array}$ \\
\hline GDP per capita & $\begin{array}{l}\text { Gross Domestic Product per capita averaged over } 10 \text { years; } \\
\text { source: World Bank }\end{array}$ \\
\hline Public debt & Public debt over GDP averaged over 10 years; source: IMF \\
\hline Trade & Trade openness averaged over 10 years; source: World Bank \\
\hline Labour participation & Labour participation rate averaged over 10 years; source: World Bank \\
\hline Import cover & Reserves over Imports averaged over 10 years; source: World Bank \\
\hline Inflation & Consumer Price Index averaged over 10 years; source: World Bank \\
\hline
\end{tabular}

To gain full insight of the central bank quality, two metrics are employed, namely rankings and marks as developed by Ramlall (2015). Both rankings and marks are inherently related since the rankings are based on the marks. The rationale for considering them separately is to shun off any feasible bias which can buffet the current analysis in that rankings tend to be more like discretized states while marks occur in continuous states. The main thrust of this paper is to gauge on whether the quality of central banks worldwide impacts on sovereign ratings and credit default swap spreads. The quality of central banks is captured by Ramlall (2015), who developed central bank rankings based on a unique set of 27 qualitative and quantitative metrics comprising of staff efficiency, publication of financial stability reports, consumer price index, language use on website for dissemination of information, research papers, z-score, information on risk

\footnotetext{
1 Based on the 10-year average, most data spanned over the period 2000 to 2012-2013.
} 
management, international accounting policy used, quality of website, adherence to green concept, contact information, IMF age maturity, notes to financial statements, presence of conferences/workshops/seminars, membership under IMF, timely reporting, professional accounting firms, stress testing, debt management, inflation targeting, power to control money supply, and other indices, as depicted in table 2 in the appendix section. Interested readers can refer to Ramlall (2015) for a detailed version of this newly developed global central bank ratings and rankings. It is of paramount significance to note that central banks which obtain higher rankings are those which exhibit poorer levels of quality in terms of the abovementioned metrics. Consequently, a negative relationship is expected to prevail between central bank quality and sovereign rankings. Based on the fact that the financial health of a central bank may affect its country's sovereign ratings, the z-score metric is incorporated as an additional explanatory variable.

Under certain cases, negative markings are undertaken to deter certain practices as in the following components: negative $\mathrm{z}$-score, incompatibility with international accounting policy, no contact information, failure to adhere to timely reporting, power to control money supply, central bank involvement in debt management task, bank regulation and supervision and governance indicators. To unleash a full-fledged ratings system for central banks, certain widely accepted measures are incorporated via outsourcing from other well-established indices such as governance indicators, central bank independence and banking regulation and supervision.

Under sovereign ratings, values ranging from 0 to 22 are assigned depending on the credit rating notch attributed by Standard and Poor's on local currency as at start of June 2014. In essence, a linear numerical scale ratings approach is used. This implies that difference between two rating categories is tantamount for any two adjacent categories. Table 4 shows the value assigned as per the ratings which are based on local currency ratings by Standard and Poor's. In the appendix section, the corresponding numerical ratings for other CRAs are found in table 5. Results are not expected to change if ratings for another CRA were to be used. As pointed out by Bozic and Magazzino (2013), spearman's correlation coefficients were very high; 0.97 between S\&P and Moody's, 0.99 between Fitch and S\&P and 0.97 between Moody's and Fitch ${ }^{2}$. The Credit Default Swap Spreads for 10-year is taken from the website of Aswath Damodaran, updated as at 2014. However, since the data is available just for 50 countries, the sample of rated central banks has been ramified accordingly, leading to 49 observations for analysis.

2 The full list of the different ratings unleashed by the other CRAs is depicted in the table found in the appendix part of the paper. 
Table 4: Marks assigned to credit ratings notch

\begin{tabular}{|c|c|c|c|c|c|}
\hline AAA & $: 22$ & BBB & $: 14$ & CCC+ & $: 6$ \\
\hline $\mathrm{AA}+$ & $: 21$ & BBB- & $: 13$ & CCC & $: 5$ \\
\hline$A A$ & $: 20$ & $\mathrm{BB}+$ & $: 12$ & CCC- : & $: 4$ \\
\hline AA- & $: 19$ & $\mathrm{BB}$ & $: 11$ & CC: & $: 3$ \\
\hline At & $: 18$ & BB- & $: 10$ & $C:$ & $: 2$ \\
\hline$A$ & $: 17$ & $\mathrm{~B}+$ & $: 9$ & D: & $: 1$ \\
\hline A- & $: 16$ & $B$ & $: 8$ & $\mathrm{NR}^{3}:$ & $: 0$ \\
\hline $\mathrm{BBB}+$ & $: 15$ & B- & $: 7$ & & \\
\hline
\end{tabular}

GDP pertains to the sum of gross value added by all resident manufacturers in a country plus any product taxes and minus any subsidies not incorporated in the value of the products. Technically speaking, the higher the rate of economic growth of a country, the easier will be the country's servicing of its existing debt burden. Jaramillo and Tejada (2011) argued that higher real GDP growth scales down borrowing costs due to stronger fiscal position. In a parallel manner, GDP per capita is considered as a vital metric of a country's development and can be deemed as a robust indicator of the tax basis available in the economy. Consequently, the higher GDP per capita for a country, the higher its propensity of being attributed of a higher rating level on the back of more space for austerity measures. Empirical studies focused on two versions of GDP, namely GDP growth and GDP per capita. Maltritz and Molchanov (2014) analyzed the determinants of default risk for emerging and developed economies using bayesian model averaging. They found that GDP growth and external debt to GDP ratio were the most vital determinants of credit rating for both emerging and developed economies. Cantor and Packer(1996) and Eichengreen and Mody (2000) found that GDP growth constituted a significant determinant of country spreads in the case of developing countries. Afonso (2003), Rowland and Torres (2004), Bissoondoyal-Bheenick (2005), Afonso et al. (2007) and Afonso et al. (2011) concluded that GDP per capita represented one of the key variables which explained the rating scale. The current study focuses on GDP per capita for two major reasons. First, Afonso (2003) found that GDP per capita, alone, constituted the most vital variable that affected ratings for developed countries. Second, Erdem and Varli (2014) did not find GDP growth variable to be significant in explaining ratings.

Erdem and Varli (2014) and Afonso et al. (2007) argued that reserves acted as the main determinant of credit ratings for emerging markets. Besides, in the case of spreads, Jaramillo and Tejada (2011) pointed out that the higher the level of inter-

\footnotetext{
3 No marks are given in the case of not rated countries.
} 
national reserves, the more the availability of resources to service foreign debt so that this scaled down the vulnerability of a country to liquidity shocks, thereby trailing behind lower spreads but only in the case of speculative grade. As stressed by Cantor and Packer (1996), international reserves represented a good indicator of the short-term distress for developing countries so that they did not factor in this variable in their study which consisted of both developing and developed countries. Bissoondoyal-Bheenick (2005) found that foreign reserves played a vital role in the determination of sovereign ratings in the case of emerging economies. Our paper resorts to a refined version of the reserves variable, namely, the import cover ratio. The latter reflects the level of imports that can be endorsed by reserves. Countries endowed with robust import cover ratios are likely to avail of enhanced level of sovereign ratings and lower credit default swap spreads.

Measured by the consumer price index, inflation reflects the yearly percentage change in the cost to the average consumer in buying a fixed basket of goods and services. A low dose of inflation is deemed as a catalyst in enshrining the level of economic activities in an economy. However, high inflation is problematic as it induces undermined credibility to monetary policy with the undermined credibility level being accentuated in the case of inflation targeting frameworks clung by central banks. In the same vein, high inflation is usually symptomatic to structural problems in government finance based on the need to monetize budget deficits. Cantor and Packer (1996) and Erdem and Varli (2014) employed inflation variable to find an inverse relationship between ratings and inflation.

Unemployment is widely perceived as an economic evil. In light of the US subprime crisis, unemployment appeared high on the agenda as the main macroeconomic concern for many governments worldwide as it entails substantial economic and social costs. With respect to studies on sovereign ratings, the recent trend has been to incorporate employment as one of the control variables as disclosed in studies undertaken by Erdem and Varli (2014) and BissoondoyalBheenick (2005) in the case of sovereign ratings and Bayoumi et al. (1995) in the case of credit spreads of US public debt. However, both Erdem and Varli (2014) and Bissoondoyal-Bheenick (2005) failed to find statistically significant impacts of unemployment. The current study resorts towards a better proxy, namely the level of labour participation in an economy. The underlying rationale emanates from the fact that labour participation directly captures the contributions of active labour force onto the economic activities of a country.

The strength of the legal system in a country is deemed to be crucial in assessing the level of protection of lenders in the case of default as extensively discussed by Panizza et al. (2009) and Bulow and Rogoff (1988). Butler and Fauver (2006) 
found that the quality of a country's legal and political institutions engendered significant effects on sovereign credit ratings. To gain full-fledged assessment of the determinants of sovereign ratings and credit default swap spreads, the strength of the legal system is incorporated as additional control variable in the model. A positive relationship is expected to prevail between the strength of the legal system and sovereign ratings while an inverse relationship is anticipated to occur between credit default swap spreads and the strength of the legal system.

Technically speaking, a government is able to repay its debt when it can alter its policy to create enough cheap savings to service its obligations. A plethora of key factors usually drive the ability of a government to be solvent, namely, maturity structure of the government debt, its currency composition, its interest rate composition and the share of debt held by local and foreign investors. Many studies have uncovered a significant and positive coefficient when regressing spreads on different fundamentals such as those of Edwards (1986), Eichengreen and Mody (1998) and Min (1998). Afonso, Furceri and Gomes (2012) pointed out that most of the literature work which dealt with the relationships between rating, yield and credit default swaps spreads, were based on emerging and developing economies. Polito and Wickens (2014) employed two versions of debt thresholds (after which default event manifests), namely ad-hoc values and a real business cycle model. In light of the US Subprime crisis of 2007/08, there is now a need to also gain insight about these relationships for advanced economies. This paper attempts to fill in this gap by having recourse towards a large sample of developed, emerging and developing countries in the world. Public debt over GDP is incorporated as an additional control metric in the model. The higher the public debt burden, the greater will be the required efforts by the government to service its obligations, and therefore a higher risk of default. Such a state of affairs underscores the significance of debt reduction efforts by speculative grade countries. Above all, as stated by Jaramillo and Tejada (2011), despite the fact that investment grade countries are endowed with some flexibility, nonetheless, they will eventually be held accountable by markets if their debt levels do not stay within comfortable zones.

Trade openness, defined as the sum of exports and imports of goods and services over GDP, is overwhelmingly applied to depict the extent of a country's involvement in international trade. Maltritz (2012) pointed out three competing explanations with respect to the impact of yield spreads. First, there is the element of willingness to pay based on the works of Eaton et al. (1986) and Eaton and Fernandez (1995). As per the willingness-to-pay studies, a country which fails to honour its payment obligations is "punished" via disruptions in trade. Consequently, more open economies have more willingness to pay incentives since they are the most affected by the punishments compared to less open countries. 
Second, more open economies are best poised to deal with crises as they are endowed with a larger value net export function relative to less open economies. An inverse relationship is expected to prevail between trade openness and yield spreads. Third, more open economies are highly vulnerable to foreign shocks or variations in the health of the world economy so that in times of crises, they are subject to higher levels of default risk. In this case, a positive relationship is anticipated to exist between yield spreads and trade openness.

The econometric models contain additional variables such as domestic credit and exchange rates. The more vibrant the domestic credit in an economy, the better will be the level of economic activities as to positively impact on sovereign ratings and negatively influence on the level of credit swap spreads. In a parallel manner, exchange rates (base currency being the US dollar) are included in the model to sieve out any external pricing competiveness effects.

\section{Results}

Summary statistics of the various variables under sovereign ratings and CDS spreads models are shown in table 6 and 7, respectively while results of the econometric estimation are depicted in table 8. Robust estimation errors are employed to ensure that results do not suffer from heteroscedasticity problem. In the same vein, the variance inflation factors ${ }^{4}$ confirm that the results are freed from any multicollinearity problems. Whether the dependent variable consists of sovereign ratings or credit default swap spreads, the impact of both versions of central bank quality, i.e., the continuous (marks) and discrete (rankings) versions of central bank quality are found to be statistically significant at the one percent significance level in most cases. In essence, a one notch increase in central bank ranking engenders around 0.1 unit decline in sovereign ratings and 0.015 unit increase in credit default swap spreads. Most importantly, the explanatory power of the econometric model significantly improves by $11^{5}$ and 9 percent when central bank quality, assessed by rankings are incorporated in the models of sovereign ratings and credit default swap spreads, respectively. In the case of the continuous metric of central bank quality, the explanatory power of the models scales up by 11 percent and 6 percent, respectively. Such a finding consolidates the quality and reliability of Ramlall (2015) rankings of central banks based on the applied rat-

4 Results can be made available to interested readers upon request.

5 This figure is obtained by comparing the $\mathrm{R} 2$ values of two regressions based on robust estimators; one regression without having the central quality variable and one regression containing it. All regression results are depicted in table 5. 
ings methodology. Most importantly, this shows that central bank quality does matter when it comes to determining sovereign ratings or credit default swap spreads. The relatively small size effects noted compared to other variables could be attributable to the fact that central bank quality is less susceptible to change rapidly over time. Such a finding is of paramount significance as it could convey a strong signal whereby central bank quality operates like a systematic component of institutional factors, as illustrated in figure 1.

Table 6: Summary statistics under Sovereign ratings model

\begin{tabular}{lrrr}
\hline \multicolumn{1}{c}{ Variable } & Mean & Min & \multicolumn{1}{c}{ Max } \\
\hline Central Bank Rankings & 57.09 & 1 & 114 \\
\hline Central Bank Marks & 49.4473 & 11.7398 & 82.4560 \\
\hline Sovereign ratings & 11.2654 & 0 & 22 \\
\hline Strength of legal system & 6.2303 & 2 & 10 \\
\hline Exchange rates & 292.4759 & 0.2899 & 9278.2 \\
\hline Inflation & 0.0595 & -0.0013 & 0.2699 \\
\hdashline Domestic credit & 0.7447 & -0.1616 & 3.1536 \\
\hline GDP per capita & 14837.3 & 297.7542 & 83732.39 \\
\hline Public debt & 0.4968 & 0.0562 & 1.8034 \\
\hdashline Trade openness & 0.9826 & 0.2568 & 3.9861 \\
\hdashline Labour participation & 0.6807 & 0.369 & 0.906 \\
\hdashline Urban population & 0.5827 & 0.1226 & 1 \\
\hline Import cover & 0.4332 & 0.0075 & 3.1500 \\
\hline Z-score & 9.1155 & -12.38 & 63.32 \\
\hline
\end{tabular}

Table 7: Summary statistics under Credit default swap spreads model

\begin{tabular}{l|rrr}
\hline \multicolumn{1}{c}{ Variable } & Mean & Min & Max \\
\hline Credit default swap spreads & 1.7424 & 0.29 & 4.57 \\
\hline Central Bank Rankings & 34.4081 & 1 & 95 \\
\hline Central Bank Marks & 56.44 & 23.29 & 77.26 \\
\hline Strength of legal system & 6.4998 & 3 & 10 \\
\hline Exchange rates & 241.4922 & 0.376 & 9278.2 \\
\hline Inflation & 0.0425 & -0.0013 & 0.2086 \\
\hline Domestic credit & 1.0657 & 0.1909 & 3.1536 \\
\hline GDP per capita & 22079.49 & 956.0491 & 69562.27 \\
\hline Public debt & 0.4876 & 0.0562 & 1.8034 \\
\hline Trade openness & 0.958 & 0.2568 & 3.6290 \\
\hline Labour participation & 0.7021 & 0.4998 & 0.8647 \\
\hline Urban population & 0.7170 & 0.2975 & 1 \\
\hline Import cover & 0.4034 & 0.0254 & 1.4147 \\
\hline Z-score & 9.1742 & -12.38 & 52.44 \\
\hline
\end{tabular}


Table 8: Results of econometric models

\begin{tabular}{|c|c|c|c|c|c|c|}
\hline Independent variables & $\begin{array}{c}\text { Sovereign } \\
\text { ratings }\end{array}$ & $\begin{array}{c}\text { Sovereign } \\
\text { ratings }\end{array}$ & $\begin{array}{c}\text { Sovereign } \\
\text { ratings }\end{array}$ & $\begin{array}{c}\text { Credit } \\
\text { default swap } \\
\text { spreads }\end{array}$ & $\begin{array}{c}\text { Credit } \\
\text { default swap } \\
\text { spreads }\end{array}$ & $\begin{array}{c}\text { Credit } \\
\text { default swap } \\
\text { spreads }\end{array}$ \\
\hline Central Bank Rankings & & $\begin{array}{r}-0.0925 \\
(-4.61)^{* * * *}\end{array}$ & & & $\begin{array}{r}0.0156 \\
(2.83)^{* * *}\end{array}$ & \\
\hline Central Bank Marks & & & $\begin{array}{r}0.1985 \\
(4.71)^{* * *}\end{array}$ & & & $\begin{array}{l}-0.0222 \\
(-2.10)^{* *}\end{array}$ \\
\hline Strength of legal system & $\begin{array}{r}0.3175 \\
(1.17)\end{array}$ & $\begin{array}{r}0.0771 \\
(0.34)\end{array}$ & $\begin{array}{r}0.0661 \\
(0.29)\end{array}$ & $\begin{array}{r}-0.1897 \\
(-2.66)^{* * *}\end{array}$ & $\begin{array}{r}-0.1477 \\
(-2.54)^{* * *}\end{array}$ & $\begin{array}{r}-0.1696 \\
(-2.55)^{* * *}\end{array}$ \\
\hline Exchange rates & $\begin{array}{r}-0.0001 \\
(-0.31)\end{array}$ & $\begin{array}{r}-0.0002 \\
(-1.00)\end{array}$ & $\begin{array}{r}-0.0001 \\
(-0.45)\end{array}$ & $\begin{array}{c}0.0001 \\
(1.82)^{*}\end{array}$ & $\begin{array}{r}0.00006 \\
(1.86)^{*}\end{array}$ & $\begin{array}{r}0.0001 \\
(2.06)^{* *}\end{array}$ \\
\hline Inflation & $\begin{array}{r}-22.4198 \\
(-1.41)\end{array}$ & $\begin{array}{r}-14.8642 \\
(-1.20)\end{array}$ & $\begin{array}{r}-16.6950 \\
(-1.37)\end{array}$ & $\begin{array}{r}4.2212 \\
(0.94) \\
\end{array}$ & $\begin{array}{r}4.2313 \\
(1.45)\end{array}$ & $\begin{array}{r}4.5732 \\
(1.27)\end{array}$ \\
\hline Domestic credit & $\begin{array}{r}2.0562 \\
(1.36)\end{array}$ & $\begin{array}{r}0.5737 \\
(0.42)\end{array}$ & $\begin{array}{r}0.4014 \\
(0.29)\end{array}$ & $\begin{array}{r}0.0647 \\
(0.24)\end{array}$ & $\begin{array}{r}0.00009 \\
(0.00)\end{array}$ & $\begin{array}{r}0.2004 \\
(0.78)\end{array}$ \\
\hline GDP per capita & $\begin{array}{r}0.0002 \\
(4.91)^{* * *}\end{array}$ & $\begin{array}{r}0.0002 \\
(4.68)^{* * *}\end{array}$ & $\begin{array}{r}0.0002 \\
(4.76)^{* * *}\end{array}$ & $\begin{array}{r}-0.00001 \\
(-1.93)^{*}\end{array}$ & $\begin{array}{r}-0.00001 \\
(-1.40)\end{array}$ & $\begin{array}{l}-0.00003 \\
(-2.79)^{* * *}\end{array}$ \\
\hline Public debt & $\begin{array}{l}-5.0604 \\
(-2.07)^{* *}\end{array}$ & $\begin{array}{r}-4.99 \\
(-2.51)^{* * *}\end{array}$ & $\begin{array}{r}-4.8698 \\
(-2.41)^{* * *}\end{array}$ & $\begin{array}{r}0.2040 \\
(0.33)\end{array}$ & $\begin{array}{r}0.2122 \\
(0.41)\end{array}$ & $\begin{array}{r}0.5564 \\
(0.91)\end{array}$ \\
\hline Trade & $\begin{array}{r}0.5871 \\
(0.69)\end{array}$ & $\begin{array}{l}1.4469 \\
(1.68)^{*}\end{array}$ & $\begin{array}{l}1.3891 \\
(1.69)^{*}\end{array}$ & $\begin{array}{r}0.1038 \\
(0.72)\end{array}$ & $\begin{array}{r}-0.1082 \\
(-0.75)\end{array}$ & $\begin{array}{r}0.0186 \\
(0.13)\end{array}$ \\
\hline Labour participation & $\begin{array}{r}8.2432 \\
(1.27)\end{array}$ & $\begin{array}{r}8.6511 \\
(1.46)\end{array}$ & $\begin{array}{r}8.9980 \\
(1.50)\end{array}$ & $\begin{array}{r}-3.5781 \\
(-1.53)\end{array}$ & $\begin{array}{l}-3.8851 \\
(-2.16)^{* *}\end{array}$ & $\begin{array}{r}-3.1645 \\
(-1.62)\end{array}$ \\
\hline Import cover & $\begin{array}{r}3.1760 \\
(2.06)^{* *}\end{array}$ & $\begin{array}{r}3.9659 \\
(2.40)^{* *}\end{array}$ & $\begin{array}{c}3.9931 \\
(2.42)^{* *}\end{array}$ & $\begin{array}{r}-0.2064 \\
(-0.53)\end{array}$ & $\begin{array}{r}-0.2526 \\
(-0.66)\end{array}$ & $\begin{array}{r}-0.7190 \\
(-1.42)\end{array}$ \\
\hline Z-score & $\begin{array}{r}-0.0115 \\
(-0.20) \\
\end{array}$ & $\begin{array}{r}0.0048 \\
(0.09)\end{array}$ & $\begin{array}{r}0.0058 \\
(0.10)\end{array}$ & $\begin{array}{r}-0.0003 \\
(-0.04)\end{array}$ & $\begin{array}{r}-0.0005 \\
(-0.08)\end{array}$ & $\begin{array}{r}-0.0002 \\
(-0.02)\end{array}$ \\
\hline Constant & $\begin{array}{r}1.3328 \\
(0.25)\end{array}$ & $\begin{array}{r}7.4227 \\
(1.62)\end{array}$ & $\begin{array}{r}-7.7163 \\
(-1.37) \\
\end{array}$ & $\begin{array}{r}5.5252 \\
(2.84)^{* * *}\end{array}$ & $\begin{array}{r}5.0524 \\
(3.26)^{* * *}\end{array}$ & $\begin{array}{r}6.5690 \\
(4.67)^{* * *}\end{array}$ \\
\hline Number of observations & 113 & 113 & 113 & 49 & 49 & 49 \\
\hline Prob $>F$ & 0.0000 & 0.0000 & 0.0000 & 0.0000 & 0.0000 & 0.0000 \\
\hline \multirow[t]{2}{*}{$F(n, m)$} & 20.49 & 20.49 & 23.07 & 13.78 & 13.24 & 15.79 \\
\hline & $F(10,102)$ & $F(11,101)$ & $F(11,101)$ & $F(10,38)$ & $F(11,37)$ & $F(11,37)$ \\
\hline R-squared & 0.4798 & 0.5906 & 0.5910 & 0.5595 & 0.6511 & 0.6163 \\
\hline
\end{tabular}

$*^{* * *}$ and ${ }^{* * *}$ denote statistical significance at the 10,5 and 1 percent significance level, respectively. 


\section{Figure 1: Central bank quality as systematic risk component}

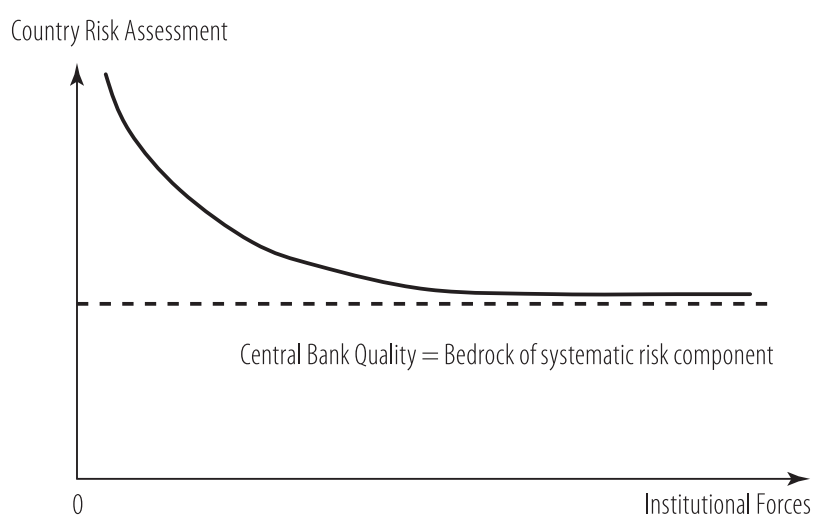

A priori, a quick glance in table 8 discloses different dynamics in operation. For instance, in the case of sovereign ratings, GDP per capita, public debt, trade openness and import cover are found to be statistically significant while in the case of CDS spreads, exchange rates, GDP per capita, labour participation and strength of the legal system are found to be the driving forces. Most importantly, all the signs are found to be compatible with our a prior theoretical foundations.

Results show that a one unit increase in GDP per capita trails behind around 0.0002 and -0.00001 impacts on sovereign ratings and CDS spreads at the one per cent significance level. Such a finding does not differ to that obtained by Erdem and Varli (2014). In fact, the latter found that GDP per capita impacted on ratings in range of 0.002 under pooled OLS (Ordinary Least Squares) estimation. The difference in impact could be due to employment of a larger sample size in the current study. The positive sign obtained is akin to the situation in which banks try to provide finer rates to borrowers which are imbued with robust collaterals having high margin covers. Conversely, the negative effect on CDS spreads is congruous with the fact that countries endowed with stronger GDP per capita base are susceptible to avail of enshrined CDS spreads. Overall, while the sign for GDP per capita is consistent with a priori theoretical foundations, nonetheless, the economic significance is not comforting. Ironically, the central bank quality variable is found to fare better than GDP per capita not only in terms of sign but also in terms of economic significance.

In spite of the fact that no significant impact of import cover on CDS spreads is noted, yet, in the case of sovereign ratings, a one unit increase in import cover engenders around 3.9 unit increase in sovereign ratings at the 5 percent signifi- 
cance level, aligned to the findings of Bissoondoyal-Bheenick (2005) though the latter resorted to reserves in lieu of import cover. Such a finding adds luster to the fact that countries which are endowed with robust import cover ratios tend to have better sovereign ratings. Such a finding also highlights the fact that the driving determinants for sovereign ratings and CDS spreads can be different. The positive impact of import cover on sovereign ratings is consistent with previous empirical studies but which clung to reserves such as those of Erdem and Varli (2014) and Afonso et al. (2007). The impotency of the import cover variable in the case of CDS spreads can be explained by the sample consisting mainly of advanced economies so that import cover is less susceptible to play a key role. Such a finding is congruous with the comment of Cantor and Packer (1996) whereby reserves play a preponderant role chiefly in the case of developing countries.

Irrespective of whether the dependent variable factors in sovereign ratings or credit default swap spreads, in both cases, no evidence is found of inflation affecting them in contrast to the results of Cantor and Packer (1996). Nevertheless, such a finding concurs with some of the previous studies which glaringly did not incorporate inflation as one of the explanatory variables in their econometric models. The impotency of inflation can be attributed to the fact that price effects are not strong enough to impound on a country's level of risk assessment. This is bolstered by the statistically insignificance results obtained in the case of exchange rates, which are statistically insignificant in the case of sovereign ratings and economically insignificant in the case of CDS spreads.

Some bouts of labour participation effects are noted chiefly in the case of CDS spreads. Indeed, a one unit increase in labour participation generates around 3.89 unit decrease in CDS spreads at the 5 percent significance level. Compared to all other explanatory variables incorporated into the CDS spreads model, labour participation is found to entail the strongest economic impact. Such a finding bodes well with the fact that the extent of labour participation in a country is crucial in impacting on its level of economic performance and thereby on its risk assessment. Above all, based on the fact that CDS spreads data are chiefly available for developed countries, such a finding glaringly underscores the significance of having a robust labour participation level in view of ensuring sound country performance. The chief underlying rationale to account for such a state of affairs relates to labour participation rate scaling down the burden of a continuously burgeoning population level, propelled by simultaneously declining death and birth rates. These findings suggest that prior studies on determinants of CDS spreads could suffer from feasible model mis-specification by utterly overlooking the level of labour participation. Above all, such a finding implies that countries which are buffeted by ageing population may be subject to higher risks of downgrades. 
The strength of the legal system is found to unleash downward pressures on credit default swap spreads only. More specifically, a one unit increase in strength of legal system trails behind around 0.15 to 0.19 decline in spreads. Such a finding adds luster to the fact that the forces which impact on sovereign ratings and CDS spreads are not likely to be the same. The negative impact noted under CDS spreads clearly shows that countries which are endowed with stronger legal systems avail of mitigated level of information asymmetry when it comes to risk assessment to thereby tap on lower levels of CDS spreads.

A one unit increase in public debt generates around 5.00 unit decline in sovereign ratings at the one percent significance level. Compared to all other variables, public debt is found to unleash the highest economic decline in sovereign ratings. Such a finding bodes well with the fact that public debts are deemed as one of the most vital country risk assessment metric. This can also be explained by the vicious circle of downgrades and burgeoning debt costs as experienced by Greece during the crisis. In the case of credit default swaps spreads, no impact is noted. This could be attributable to the fact that the dynamics of fundamentals tend to be different with respect to sovereign credit ratings and credit default swaps spreads. In addition, this could be due to sample size effects. As emphasized by Jaramillo and Tejada (2011), investment grade countries are endowed with some flexibility in debt reductions compared to speculative grade countries so that the risk levels are not the same for different countries.

Trade openness variable is found to be impotent in the case of CDS spreads. In the case of sovereign ratings, a one unit increase in trade openness is found to trigger around 1.38 to 1.45 unit increase in sovereign ratings. The positive effect is compatible with the fact that countries which are endowed with higher levels of trade openness are likely to experience less default risk as to avail of a higher level of sovereign ratings. The underlying rationale draws from willingness-topay concepts of Eaton et al. (1986) and Eaton and Fernandez (1995). Neither domestic credit nor z-score are found to affect sovereign ratings and credit default swap spreads.

\section{Endogeneity issue due to omitted variable bias}

It is likely that our results are buffeted by endogeneity problem, generated by the omitted variable bias problem. The coefficients obtained for central bank quality may thereby be subject to upward or downward bias. To circumvent such a problem, we cling to instrumental variable. We posit that central bank quality tends to be strongly linked to the level of deposits held in central banks as a theoretical 
construct. The underlying rationale relates to the fact that better central banks tend to be endowed with stronger deposit base akin to commercial banks which lure more deposits in the case of sound performance and maintained credibility. We further explore other central bank specific variables such as net interest income, size of employees, investment, notes and coins issued, level of foreign assets held, gold held and capital from a statistical point of view. Overall, findings show that deposits held constitutes the best proxy to capture the quality of central banks out of the plethora of central bank specific variables considered. Hence, deposits satisfy both the theoretical and technical conditions to be eligible as an instrumental variable in our model.

Consequently, we implement the Hausman test for endogeneity. We run the reduced-form model consisting of central bank quality as the dependent variable and all independent variables including the instrumental variable as additional explanatory variable in the model. The effect of deposits is found to be both economically and statistically (at one per cent level) significant. The residuals of the reduced-form model are then used as explanatory variable in the structural model. Results are shown in table 9 in the appendix section with the residuals being statistically insignificant and thus satisfying the requirement of our model. Ironically, when endogeneity issue is taken into consideration, the impact of central bank quality on sovereign ratings slightly improves. Therefore, strong evidence prevails as to the effect of central bank quality on sovereign ratings.

\section{Conclusion}

Sovereign ratings and credit default swap spreads constitute key variables whenever gauging on country risk levels. This paper contributes to the empirical literature on determinants of both sovereign ratings and credit default swap spreads by giving due consideration to the quality of central banks worldwide. Findings show that central bank quality does influence both sovereign ratings and credit default swap spreads. Interestingly, the explanatory power of the model improves by 11 percent and 6 to 9 percent when central bank quality variable is incorporated in the sovereign ratings and credit default swap spreads models, respectively. Such a finding implies that central bank quality could be deemed as a systematic component or the bedrock component whenever assessing country risk levels. In addition, results glaringly show that the driving forces for sovereign ratings and CDS spreads tend to be different. GDP per capita, public debt, trade openness and import cover constitute the forces which impound on sovereign ratings while exchange rates, GDP per capita, labour participation and the strength of the legal system are found to impact on CDS spreads. All signs obtained are found to be 
fully compatible with theoretical foundations. Interestingly, among all the variables considered, the strongest effects for sovereign ratings emanate from public debt and import cover while the strength of the legal system is found to be the most robust variable which influences CDS spreads worldwide.

No effect of import cover on CDS spreads is noted, consistent with the comments of Cantor and Packer (1996) whereby reserves play a key role chiefly in the case of developing countries. In the case of sovereign ratings, a positive relationship between import cover and sovereign ratings is found. Such a finding adds luster to the fact that countries which are endowed with robust import cover ratios tend to have better sovereign ratings, not incongruous with empirical studies on reserves undertaken by Erdem and Varli (2014) and Afonso et al. (2007). Pricing effects, either via inflation or exchange rates are not found to be operating. Such a finding is vital as it shows that local or external price manipulations are unlikely to improve a country risk level.

Labour participation is found to be a determinant in the case of CDS spreads. Such a finding signifies that labour involvement is key to enhanced state of economic activities. Countries buffeted by stronger effects of ageing population could witness higher risks of downgrades. Similarly, the strength of the legal system exerts bearing pressures on the level of CDS spreads, substantiating the fact that countries which have established robust legal systems, are likely to enjoy lower risks which thereby translate into lower levels of CDS spreads.

Public debt negatively impacts on sovereign ratings of countries in the world. Countries found in high public debt zones should thereby engage in debt reduction to ensure they are not subject to exorbitant costs when they contemplate to raise new funds. The irony of such a state of affairs is that growth levels are still at mild or below satisfactory zone for most countries in the world so that efforts to scale down debts are susceptible to extremely difficult but highly rewarding in subduing adverse repercussion on growth potential. Trade openness positively affects sovereign ratings, consistent with the fact that the more open an economy is, the more likely that it will be subject to "punishments" in the case of solvency problems.

The major contribution force of this paper is that previous models of sovereign ratings and CDS spreads assessments are likely to suffer from model mis-specification by overlooking the core component of institutional quality assessment, namely, the central bank quality. 


\section{Appendix}

Table 1: List of countries

\begin{tabular}{|c|c|c|c|c|c|}
\hline AFGHANISTAN & BULGARIA & GHANA & KOSOVO & NETHERLANDS & SLOVENIA \\
\hline ALBANIA & CANADA & GREECE & KUWAIT & NEW ZEALAND & $\begin{array}{l}\text { SOLOMON } \\
\text { ISLANDS }\end{array}$ \\
\hline ARMENIA & $\begin{array}{l}\text { CAYMAN } \\
\text { ISLANDS }\end{array}$ & GUYANA & Kyrgyz Republic & NIGERIA & SOUTH AFRICA \\
\hline ARUBA & TAIWAN & HAITI & LATVIA & NORWAY & SPAIN \\
\hline AUSTRALIA & CHILE & HONG KONG & LESOTHO & OMAN & SRI LANKA \\
\hline AUSTRIA & CROATIA & HUNGARY & LITHUANIA & PAKISTAN & SWEDEN \\
\hline AZERBAIJAN & CYPRUS & ICELAND & LUXEMBOURG & $\begin{array}{l}\text { PAPUA NEW } \\
\text { GUINEA }\end{array}$ & SWITZERLAND \\
\hline BAHAMAS & $\begin{array}{l}\text { CZECH } \\
\text { REPUBLIC }\end{array}$ & INDIA & MACEDONIA & PERU & TAJIKISTAN \\
\hline BAHRAIN & DENMARK & INDONESIA & MADAGASCAR & PHILIPPINES & TANZANIA \\
\hline BANGLADESH & $\begin{array}{l}\text { EAST } \\
\text { CARRIBEAN } \\
\text { COUNTRIES }\end{array}$ & IRAN & MALAWI & POLAND & THAILAND \\
\hline BARBADOS & UK & IRAQ & MALAYSIA & PORTUGAL & TONGA \\
\hline BELARUS & ESTONIA & IRELAND & MALTA & ROMANIA & $\begin{array}{l}\text { TRINIDAD and } \\
\text { TOBAGO }\end{array}$ \\
\hline BELGIUM & USA & ISRAEL & MAURITIUS & RUSSIA & TUNISIA \\
\hline BELIZE & FIJI & ITALY & MOLDOVA & RWANDA & TURKEY \\
\hline BERMUDA & FINLAND & JAMAICA & MONGOLIA & SAMOA & UGANDA \\
\hline BHUTAN & FRANCE & JAPAN & MONTENEGRO & SERBIA & UKRAINE \\
\hline $\begin{array}{l}\text { BOSNIA and } \\
\text { HERZEGOVINA }\end{array}$ & GAMBIA & KAZAKHSTAN & MOZAMBIQUE & SEYCHELLES & $\begin{array}{l}\text { UNITED ARAB } \\
\text { EMIRATES }\end{array}$ \\
\hline BOSTWANA & GEORGIA & KENYA & NAMIBIA & SINGAPORE & VANUATU \\
\hline BRAZIL & GERMANY & KOREA & NEPAL & SLOVAKIA & ZAMBIA \\
\hline
\end{tabular}


Table 3: Metrics employed by Ramlall (2015) Central Bank Ratings

\begin{tabular}{l} 
Metrics of assessment \\
Staff efficiency \\
Publication of Financial Stability Report \\
Consumer Price Index-Price stability \\
Language on website \\
Research Papers \\
Z-Score \\
Risk Management information \\
International accounting policy used \\
Quality of website \\
Adherence to green concept \\
Contact information \\
IMF above mean age \\
Notes to financial statements \\
Conferences/Workshops/Seminars \\
IMF member \\
\hline Timely reporting \\
Professional Accounting Firms \\
Stress Testing \\
Debt management \\
Inflation targeting \\
Power to control money supply \\
Central Bank Independence \\
Bank Regulation and Supervision: \\
(i) change in the index of bank capital regulations \\
(ii) change in the index of deposit insurance \\
(iii) change in the index of official supervisory powers \\
Global Regulatory framework for banks under under Basel III \\
Worldwide Governance Indicators \\
\hline
\end{tabular}


Table 5: Different rankings for different rating agencies

\begin{tabular}{|c|c|c|c|c|}
\hline Moody's & S\&P & Fitch & Explanation & Rank \\
\hline Aaa & AAA & AAA & Prime & 1 \\
\hline Aal & $\mathrm{AA}+$ & AA+ & & 2 \\
\hline Aa2 & AA & AA & High grade & 3 \\
\hline $\mathrm{Aa3}$ & AA- & AA- & & 4 \\
\hline A1 & $A+$ & $A+$ & & 5 \\
\hline $\mathrm{A} 2$ & $A$ & A & Upper medium grade & 6 \\
\hline A3 & $A-$ & $A-$ & & 7 \\
\hline Baal & $\mathrm{BBB}+$ & $\mathrm{BBB}+$ & & 8 \\
\hline Baa2 & $\mathrm{BBB}$ & $\mathrm{BBB}$ & Lower medium grade & 9 \\
\hline Baa3 & $\mathrm{BBB}-$ & BBB- & & 10 \\
\hline Ba1 & $\mathrm{BB}+$ & $\mathrm{BB}+$ & Non-investment grade & 11 \\
\hline $\mathrm{Ba} 2$ & $\mathrm{BB}$ & $\mathrm{BB}$ & Speculative & 12 \\
\hline $\mathrm{Ba3}$ & $\mathrm{BB}-$ & BB- & & 13 \\
\hline B1 & $\mathrm{B}+$ & $\mathrm{B}+$ & & 14 \\
\hline B2 & B & B & Highly speculative & 15 \\
\hline B3 & B- & $\mathrm{B}^{-}$ & & 16 \\
\hline Caal & $\mathrm{CCC}+$ & & Substantial risks & 17 \\
\hline Caa2 & CCC & & Extremely speculative & 18 \\
\hline \multirow[t]{2}{*}{ Caa3 } & CCC- & $\mathrm{CCC}$ & \multirow[t]{2}{*}{ Poor quality } & 19 \\
\hline & $\mathrm{CC}$ & & & 20 \\
\hline \multirow[t]{2}{*}{$\mathrm{Ca}$} & & & \multirow[t]{2}{*}{ Recovery prospects } & \\
\hline & C & & & 21 \\
\hline C & C & DDD & Default & 22 \\
\hline
\end{tabular}

Source: Standard \& Poor's, Moody's Investors Service and Fitch Rating Agency 
Table 9: Endogeneity Issue under Sovereign Ratings

\begin{tabular}{|c|c|c|}
\hline Variables & No control & Control \\
\hline \multirow[t]{2}{*}{ Central Bank Rankings } & $-0.0925^{* * *}$ & $-0.0964^{* * *}$ \\
\hline & $(0.0200)$ & $(0.0213)$ \\
\hline \multirow[t]{2}{*}{ Residuals } & & 0.0555 \\
\hline & & $(0.0725)$ \\
\hline \multirow[t]{2}{*}{ Strength of legal system } & 0.0771 & 0.211 \\
\hline & $(0.230)$ & $(0.310)$ \\
\hline \multirow[t]{2}{*}{ Exchange rates } & -0.000212 & -0.000176 \\
\hline & $(0.000213)$ & $(0.000244)$ \\
\hline \multirow[t]{2}{*}{ Inflation } & -14.86 & -19.08 \\
\hline & $(12.37)$ & (14.10) \\
\hline \multirow[t]{2}{*}{ Domestic credit } & 0.574 & 1.401 \\
\hline & $(1.354)$ & $(1.358)$ \\
\hline \multirow[t]{2}{*}{ GDP per capita } & $0.000173^{* * *}$ & $0.000184^{* * *}$ \\
\hline & $(3.70 \mathrm{e}-05)$ & (3.87e-05) \\
\hline \multirow[t]{2}{*}{ Public debt } & $-4.997^{* *}$ & $-5.032^{* *}$ \\
\hline & (1.987) & $(1.958)$ \\
\hline \multirow[t]{2}{*}{ Trade openness } & $1.447^{*}$ & 0.967 \\
\hline & $(0.860)$ & $(1.016)$ \\
\hline \multirow[t]{2}{*}{ Labour participation } & 8.651 & 8.424 \\
\hline & $(5.922)$ & $(5.973)$ \\
\hline \multirow[t]{2}{*}{ Import cover } & $3.966^{* *}$ & $3.525^{* *}$ \\
\hline & $(1.650)$ & $(1.706)$ \\
\hline \multirow[t]{2}{*}{ Z-score } & 0.00485 & -0.00427 \\
\hline & $(0.0568)$ & $(0.0575)$ \\
\hline \multirow[t]{2}{*}{ Constant } & 7.423 & 4.026 \\
\hline & $(4.568)$ & $(6.579)$ \\
\hline Observations & 113 & 113 \\
\hline R-squared & 0.591 & 0.593 \\
\hline
\end{tabular}

Robust standard errors in parentheses

*** $p<0.01,{ }^{* *} p<0.05,{ }^{*} p<0.1$ 


\section{References}

1. Afonso, A., 2003. Understanding the determinants of sovereign debt ratings: evident for the two leading agencies. Journal of Economics and Finance 27 (1), 56-74.

2. Afonso, A., P. Gomes, and Rother, P. (2007). What hides behind sovereign debt ratings?, ECB WorkingPaper Series, 711, January.

3. Afonso, A., Gomes, P., 2011. Do fiscal imbalances deteriorate sovereign debt ratings? Revue Économique 62 (6).

4. Afonso, A., Furceri, D. and Gomes, P. (2012). Sovereign credit ratings and financial markets linkages: Application to European data. Journal of International Money and Finance, 21, pp. 606-638.

5. Alesina, A., De Broeck, M., Prati, A. andTabellini, G., 1992. Default risk on government debt in OECD countries. Economic Policy 15, pp. 428-463.

6. Alsakka, R. and O. Gwilym (2010). Leads and lags in sovereign credit ratings, Journal of Banking and Finance. 34: 2614-2626.

7. Damodaran, A. (2014). Website available at: [http://pages.stern.nyu. edu/ adamodar/]

8. Bayoumi, T., Goldstein, M., and Woglom, G., 1995. Do credit markets discipline sovereign borrowers? Evidence from US states.Journal of Money Credit and Banking 27, pp. 1046-1059.

9. Bissoondoyal-Bheenick., E. (2005). An Analysis of the Determinants of Sovereign Ratings. Global Finance Journal 15, pp. 251-280.

10. Bozic, V. and Magazzino, C. (2013). Credit Rating Agencies: The Importance of Fundamentals in the Assessment of Sovereign Ratings. Economic Analysis and Policy, Vol. 43, No. 2, pp. 157-176.

11. Bulow, J. and K. Rogoff (1988). Sovereign Debt Restructurings: Panacea or Pangloss?, NBER WorkingPapers, 2637.

12. Butler, A. W. and Fauver, L. (2006). Institutional Environment and Sovereign Credit Ratings. Financial Management, Vol. 35, No. 3, pp. 53-79.

13. Cantor, R., and Packer, F. (1996). Determinants and impact of sovereign credit rating. Federal Reserve Bank of New York Economic Policy Review, (October), 1-15.

14. Cavallo, E. A., and Valenzuela, P. (2010). The determinants of corporate risk in emerging markets: An option-adjusted spread analysis. International Journal of Finance and Economics, 15, 59-74.

15. Eaton, J., and Fernandez, R. (1995). Sovereign debt. NBER working paper 5131.

16. Eaton, J., Gersovitz, M., and Stiglitz, J. (1986). The pure theory of country risk. European Economic Review, 30, 481-513. 
17. Edwards, S. (1986). The Pricing of Bonds and Bank Loans in International Markets, An Empirical Analysis of Developing Countries' Foreign Borrowing, European Economic Review 30, 565-589.

18. Eichengreen, B. and Mody, A. (1998). What Explains Changing Spreads on Emerging-Market Debt:Fundamentals or Market Sentiment?, NBER Working Paper, 6408.

19. Eichengreen, B., andMody, A. (2000). What explains changing spreads on emerging-market debt: Fundamentals or market sentiment. In S. Edwards (Ed.), Capital flows and the emerging economies: Theory, evidence and controversies. University of Chicago Press.

20. Erdem, O. and Varli, Y. (2014). Understanding the sovereign credit ratings of emerging markets. Emerging Markets Review 20, pp. 42-57.

21. Ferri, G., Liu, L. and Stiglitz, J.E. (1999). The Procyclical Role of Rating Agencies: Evidence from the East Asian Crisis. Economic Notes, Vol. 28, No. 3, pp. 335-355.

22. González-Rozada, M. and Yeyati, E. L. (2008), Global Factors and Emerging Market Spreads. The Economic Journal, 118, pp.1917-1936.

23. Guttler, A. and Wahrenburg, M. (2007). The adjustment of credit ratings in advance of defaults, Journal of Banking and Finance,31, pp. 751-767.

24. Hartelius, K., Kashiwase, K. and Kodres, L.E. (2008). Emerging Market Spread Compression: Is it Real or is it Liquidity?. IMF Working Paper 08/10.

25. Hill, P., Brooks, R., Faff, R., 2010. Variations in sovereign credit quality assessments across rating agencies. Journal of Banking and Finance 34 (6), 1327-1343.

26. Jaramillo, L., Tejada, M. (2011). Sovereign credit ratings and spreads in emerging markets: does investment grade matter? IMF Working Papers, pp. 1-17.

27. Kaminsky, G. and S. Schmukler. (2002). Emerging market Instability: Do Sovereign Ratings Affect Country Risk and Stock Returns? The World Bank Economic Review, Vol. 16, No. 2, pp. 171-195.

28. Klein, C. and Stellner, C. (2014). Does sovereign risk matter? New evidence from eurozone corporate bond ratings and zero-volatility spreads. Review of Financial Economics, 23, pp. 64-74.

29. Maltritz, D. (2012). Determinants of sovereign yield spreads in the Eurozone: A Bayesian approach. Journal of International Money and Finance, 31, 657-672.

30. Maltritz, D., \&Molchanov, A. (2014). Country credit risk determinants with model uncertainty. International Review of Economics and Finance, 29, 224-234. 
31. Min, H. (1998). Determinants of emerging market bond spread: Do economic fundamentals matter? World Bank policy research working paper 1899.

32. Oliveira, L., Curto, J.D., and Nunes, J.D. (2012). The determinants of sovereign credit spread changes in the Euro-zone. Journal of International Financial Markets, Institutions and Money, 22, pp. 278-304.

33. Panizza, U., Strurzenegger, F., \&Zettelmeyer, J. (2009). The economic and law of sovereign debt and default. Journal of Economic Literature, 3(3), 651698.

34. Polito, V. and Wickens, M. (2014). Modelling the U.S. sovereign credit rating. Journal of Banking and Finance, 46, pp. 202-218.

35. Ramlall, I. (2015). Global Central Bank Ratings: A New Methodology for Global Excellence. Palgrave Macmillan.

36. Rowland, P. and J.L. Torres (2004). Determinants of spread and creditworthiness for emerging market sovereign debt: A panel data study, Banco de la Republica de Colombia, 296.

37. Sy, A. (2002). Emerging Market Bond Spreads and Sovereign Credit Ratings: Reconciling Market Views with Economic Fundamentals. Emerging Markets Review, 3, pp, 380-408. 